\title{
Evaluation of Dietary Supplementation of Ajwain on the Hematological and Economical Parameters of Pratapdhan Chickens
}

\author{
Anurag $^{1}$, Sarita Kumari ${ }^{2 *}$ and Attar Uddin $^{3}$
}

${ }^{1}$ Livestock Production and Management, Mahatma Jyotiba Fule College of Veterinary and Animal Science, Chomu, (Rajasthan University of Veterinary and Animal Sciences, Bikaner), Jaipur, India

${ }^{2}$ Livestock Products Technology, Post Graduate Institute of Veterinary Education and Research, (Rajasthan University of Veterinary and Animal Sciences, Bikaner), Jaipur, India

${ }^{3}$ Livestock Production and Management, Sri Karan Narendra Agriculture University, Jobner, Jaipur, India

*Corresponding author

\section{A B S T R A C T}

The present experiment was conducted to investigate the effect of dietary supplementation of Ajwain on the hematological response and economical parameter/benefit cost ratio of Pratapdhan chickens. An experiment was conducted on 120 unsexed Pratapdhan chicks (day old) randomly design in 4 treatment groups with 3 replicates, each consisting of 10

Keywords

Dietary supplementation, Hematological parameters

\section{Article Info}

Accepted:

04 January 2018

Available Online:

10 February 2018 chicks. Three treatment groups were as follows $-\mathrm{T}_{1}$ : Basal diet as per BIS standards 2007; $\mathrm{T}_{2}$ : Basal diet as per BIS standards 2007 supplemented with $0.1 \%$ Ajwain; $\mathrm{T}_{3}$ : Basal diet as per BIS standards 2007 supplemented with $0.2 \%$ Ajwain; and $\mathrm{T}_{4}$ : Basal diet as per BIS standards 2007 supplemented with $0.3 \%$ Ajwain. The chicks were kept under uniform managemental conditions on deep litter system from day 0 up to $8^{\text {th }}$ weeks of age. Among the hematological parameters, $\mathrm{Hb}$ found highest in $\mathrm{T}_{3}(11.9 \pm 0.57)$ followed by $\mathrm{T}_{2}$ (11.47 \pm 0.38$), \mathrm{T}_{4}(11.37 \pm 0.21)$ and $\mathrm{T}_{1}(10.50 \pm 0.36), \mathrm{PCV}$ found highest in $\mathrm{T}_{4}(40.45 \pm 0.11)$ followed by $\mathrm{T}_{3}(40.18 \pm 0.07), \mathrm{T}_{2}(39.40 \pm 0.13)$ and $\mathrm{T}_{1}(37.63 \pm 0.54)$, TEC found better in $\mathrm{T}_{3}$ (11.9 \pm 0.57$)$ followed by $\mathrm{T}_{2}(11.47 \pm 0.38), \mathrm{T}_{4}(11.37 \pm 0.21)$ and $\mathrm{T}_{1}(2.0 \pm 0.36)$, TLC found better in $\mathrm{T}_{3}(28.02 \pm 0.03)$ followed by $\mathrm{T}_{4}(28.01 \pm 0.04), \mathrm{T}_{2}(27.66 \pm 0.10)$ and $\mathrm{T}_{1}$ (26.08 \pm 0.06$)$. The highest Benefit cost ratio (1.85) was observed in $\mathrm{T}_{3}$ groups followed by $\mathrm{T}_{2}$ (1.78), $\mathrm{T}_{1}(1.70)$, and $\mathrm{T}_{4}(1.67)$. On the basis of the result of the present study, it is concluded that dietary addition of Ajwain at the $0.2 \%$ level was found beneficial in improving hematological profile. It can also be concluded that Ajwain can be used as efficient, effective and economical alternative to chemical growth promoters in poultry industry.

\section{Introduction}

The broiler industry has gained an incredible growth over the past few decades in commercial poultry production. The broiler meat is easily available, cost effective and a good source of animal origin protein without any social tabbo (Sarkar et al., 2008). Feed is 
the major part of total prices of poultry venture as $80 \%$ of the entire expenditure is on the procurement of feed. Feed additives are a group of nutrient and non-nutrient compounds which helps in raising the potency of feed utilization and therefore reducing the high cost of feed. Since long time, antibiotics growth promoter in animal feeds had positive impact on feed conversion efficiency and growth performance of chicken. However, the inclusion of those feed additives will increase not only the cost of production, however additionally increases the development of resistant microbes, produces residues in meat and eggs and alter the natural gut microbiota (Sojoudi et al., 2012; Yang et al., 2009). As a result, to replace them without adversely poignant the performance of birds, natural growth promoters like probiotics, probiotics, synbiotics, enzymes, plant extracts, etc., can be used to feed the broilers. Kabir, 2009 reported that the antibiotic ban, increasing the prevalence of resistance in poultry industry. Therefore, there is a paradigm shift from chemical growth promoter to phytogenic growth promoters.

In the last decade, herbal feed additives have attracted the attention of scientists as useful resource for improving productivity. Herbs could be expected to serve as feed additives due to their suitability and preference, reduced risk of toxicity, no residues in meat, lower cost of production, minimum health hazards and environmental friendliness (Devegowda, 1996). Further, the phenols and other active ingredients of herbs help in reducing the parasite load which affects health and performance of poultry (Akhtar et al., 1984). Ajwain (Trachyspermum ammi L.) is an aromatic, grassy and annual medicinal plant belonging to Apiaceae (Umbelliferae) family. The Rajasthan, Gujarat and Madhya Pradesh are main Ajwain growing states in India. Ajwain is highly esteemed as a remedial agent for flatulence, flatulent colic, atonic dyspepsia, diarrhoea - in short, as a digestive aid and also as an antiseptic (Bentely and Wrimen, 1999). Ajwain, is reported to have platelet aggregation inhibitory action (Srivastava, 1988), antifungal potency (Dwivedi and Dubey, 1993) and blood pressure lowering action (Aftab et al., 1995). Keeping in view the facts stated above, the present study was planned to study the effect of Ajwain supplementation in poultry diet on the haematological parameters and benefit cost ratio Pratapdhan breed of chicken.

\section{Materials and Methods}

The experiment was conducted at Poultry farm, S.K.N. College of Agriculture, Jobner District Jaipur, (Rajasthan, India). Geographically Jobner is located $45.0 \mathrm{~km}$ west of Jaipur at $26^{\circ} 05^{\prime}$ North latitude, $75^{\circ} 28^{\prime}$ East longitude and at an altitude of 427 meter above the mean sea level. The area falls in agro-climatic zone III-A (Semi-arid eastern plain zone of Rajasthan). The 120 chicks (day old) of Pratapdhan breed of chicken were procured from the project "Aangan me Murgi palan”, funded by R.K.V.Y. (Rashtriya Krishi Vikas Yojana) running in the department of Livestock Production Management at Sri Karan Narendra College of Agriculture, Jobner. The chicks were randomly distributed over four treatment groups each having 30 chicks. Each of the treatment was replicated three times, with ten birds per replicate in a Completely Randomized Design (CRD). Good quality Ajwain seed was purchased from the local market in one slot. The seed were grind to fine powder and mixed properly at appropriate concentrations in the feed as specified for different treatments. The chicks were offered all crumbled chick starter feed $a d$ libtum, purchased from a private poultry feed manufacturing factory according to BIS (2007) specifications listed in Table 1. $T_{1}$ group was provided standard chick ration as per BIS (2007) specifications without any 
supplementation and served as control, $\mathrm{T}_{2}$ received standard chick ration with Ajwain powder supplementation in feed @ $0.1 \%, \mathrm{~T}_{3}$ standard chick ration with Ajwain powder supplementation in feed @ $0.2 \%$ and $\mathrm{T}_{4}$ standard chick ration with Ajwain powder supplementation in feed @ $0.3 \%$. The experimental birds were nearly equal in the live body weight at the start of the experiment. The experiment was extended up to 8 weeks of age. Feed and water were supplied adlibitum during the experimental periods. Chicks were grown in brooders with raised wire floors and exposed to 24 hours of constant light (12 hrs on day light and the rest on artificial lighting, using 40 watt bulbs). All chicks were kept under the same environmental and hygienic conditions. Live weight and feed consumption were recorded during the experiment period.

\section{Hematological parameter}

\section{Collection of blood sample}

Blood collection was carried out at the end of $8^{\text {th }}$ week of the experiment. The analysis of blood samples was carried at laboratory of state government located at Disease Diagnostic Lab, Gopinath marg, Panch batti, Jaipur. Eight birds from each replication of every treatment were randomly selected for blood collection. Disposable syringes with needles were used to collect blood from the wing veins. The blood was transferred immediately into a set of sterile plastic tubes with and without anti-coagulant for haematological test. The test tubes were held in slanting position for serum separation. The serum was centrifuged to remove the erythrocytes present, if any. The clear, nonhaemolysed sera then collected in clean, dry and labelled vials. The blood samples were analyzed for Hemoglobin ( $\mathrm{Hb})$, Total erythrocyte count (TEC), Packed cell volume (PCV) and Total leucocyte count (TLC).

\section{Analysis of blood samples}

Hemoglobin estimation was done using Hellige hemometer method as described by Lamberg and Rothstein (1977). The analysis of Total erythrocyte count (TEC), Total leucocyte count (TLC) and Packed cell volume (PCV) were also done by method developed by Lamberg and Rothstein (1977).

\section{Economic parameter}

\section{Benefit cost ratio}

The benefit cost ratio was calculated on the basis of cost of raising the chicks which include the cost of chicks, feed, vaccine, Ajwain, labour and price of birds at the end of experimental period. All the expenditures and income was calculated on the basis of prevailing market rates and rate approved by the college as follows in Table 2 .

\section{Statistical analysis}

Data obtained were subjected to statistical analysis as per Snedecor and Cochran (1994) using Completely Randomized Design (CRD). All the data were subjected to ANOVA using the General Linear Models procedure of SAS software (SAS Institute, 2003). The mean differences among different treatments were separated by Duncan's multiple range tests. Consequently, a level of $(\mathrm{P}<0.05)$ was used as the criterion for statistical significance (Duncan, 1955).

\section{Results and Discussion}

\section{Hematological parameter}

The results of hematological parameters of Pratapdhan chicken at 56 day are presented in Table 3. The results of hematological parameters showed significant $(\mathrm{P}<0.05)$ differences in the values of $\mathrm{Hb}, \mathrm{PCV}$, TEC 
and TLC which were significantly higher in $\mathrm{T}_{3}$ than control.

The range of Hemoglobin and PCV were 10.5 $\left(\mathrm{T}_{1}\right)$ to $11.9\left(\mathrm{~T}_{3}\right) \mathrm{g} / \mathrm{dl}$ and $37.63\left(\mathrm{~T}_{1}\right)$ to 40.18 $\left(\mathrm{T}_{3}\right) \%$, respectively. Total erythrocytes count (TEC) and total leucocytes count (TLC) among treatment groups ranging from 2.64 $\left(\mathrm{T}_{1}\right)$ to $2.76\left(\mathrm{~T}_{3}\right)$ millions $/ \mathrm{mm}^{3}$ and $26.08\left(\mathrm{~T}_{1}\right)$ to $28.02\left(\mathrm{~T}_{3}\right)$ thousands $/ \mathrm{mm}^{3}$, respectively. Similar, results were reported by Siddqui et al., (2007) and Sethy et al., (2016).

However, Yadava et al., (2009) and Elagib et al., (2013) found non-significant difference in the Hemoglobin, PCV, TEC and TLC values among treatment groups. The difference in the values of lymphocyte, Monocyte, Heterophil, Eosinophil and Basophil was non-significant. The similar results were also reported by
Yadava et al., (2009) with broiler diet supplemented with enzyme and Elagib et al., (2013) with supplementation of garlic.

\section{Economic parameter}

\section{Benefit cost ratio}

The cost of production of Pratapdhan chicken, considering the cost of chicks, feed consumed, Ajwain, vaccine and labour cost up to 8 weeks of age, reared under different treatments is presented in Table 4. The experiment was started with 30 birds in each treatment group. The initial cost of Pratapdhan was Rs. 35.00 per chick. Feed cost was calculated @ Rs. 26.4 per $\mathrm{kg}$ of feed. Vaccination and labour cost estimated rupees 5.00 and 8.75 for each chick, respectively. Ajwain was purchased @ $250 \mathrm{Rs} . / \mathrm{Kg}$ from local market.

Table.1 Specifications for chick starter feed (BIS Standards 2007)

\begin{tabular}{|l|l|l|l|}
\hline No & Nutrient & Unit & Chick \\
\hline 1 & Moisture & Max \% & 11.00 \\
\hline 2 & Crude Protein & Min\% & 20.00 \\
\hline 3 & Ether Extract & Min\% & 02.00 \\
\hline 4 & Crude Fibre & Max\% & 07.00 \\
\hline 5 & Ash & Max\% & 04.00 \\
\hline 6 & Salt as Nacl & Max\% & 0.50 \\
\hline 7 & Lysine & Min\% & 01.00 \\
\hline 8 & Methionine & Min\% & 0.45 \\
\hline 9 & Methionine + cystine & Min\% & 0.70 \\
\hline 10 & Metabolizable energy & Min\% Kcal/kg & 2800 \\
\hline 11 & Calcium & Max \% & 01.00 \\
\hline 12 & Phosphorous & Min\% & 0.70 \\
\hline 13 & Available P & & 0.45 \\
\hline 14 & Manganese & Min mg & 60.00 \\
\hline 15 & Iron & Min mg & 01.00 \\
\hline 16 & Copper & Min mg & 70.00 \\
\hline 17 & Selenium & Min mg & 12.00 \\
\hline 18 & Zinc & Min mg & 0.15 \\
\hline & & Min mg & 60.00 \\
\hline
\end{tabular}


Table.2 Various items cost

\begin{tabular}{|l|l|l|l|}
\hline No. & Item & Cost (Rupees) & Source of cost \\
\hline 1 & Chicks & $35 /$ chick & Actual purchase rate \\
\hline 2 & Labour & $8.75 /$ chick & Approved college rate \\
\hline 3 & Feed & $26.4 / \mathrm{kg}$ & Approved college rate \\
\hline 4 & Ajwain & $250 / \mathrm{kg}$ & Local market \\
\hline 5 & Vaccination & $5 /$ chick & Local market \\
\hline 6 & Chicks live weight & $200 / \mathrm{kg}$ & Approved college rate \\
\hline
\end{tabular}

Table.3 Effect of Ajwain on mean hematological parameters of Pratapdhan chicken at 56 day

\begin{tabular}{|c|c|c|c|c|c|}
\hline Parameter & Unit & $T_{1}$ & $T_{2}$ & $T_{3}$ & $\mathrm{~T}_{4}$ \\
\hline $\mathrm{Hb}$ & $\mathrm{g} / \mathrm{dl}$ & $10.50^{b} \pm 0.36$ & $11.47^{\mathrm{a}} \pm 0.38$ & $11.90^{\mathrm{a}} \pm 0.57$ & $11.37^{\mathrm{ab}} \pm 0.21$ \\
\hline PCV & $\%$ & $37.63^{c} \pm 0.54$ & $39.40^{\mathrm{b}} \pm 0.13$ & $40.18^{\mathrm{ab}} \pm 0.07$ & $40.45^{\mathrm{a}} \pm 0.11$ \\
\hline TEC & millions $/ \mathrm{mm}^{3}$ & $02.64^{c} \pm 0.023$ & $02.71^{b} \pm 0.012$ & $02.76^{\mathrm{a}} \pm 0.008$ & $02.75^{\mathrm{a}} \pm 0.003$ \\
\hline$\overline{\text { TLC }}$ & thousand $/ \mathrm{mm}^{3}$ & $26.08^{c} \pm 0.06$ & $27.66^{b} \pm 0.10$ & $28.02^{\mathrm{a}} \pm 0.03$ & $28.01^{\mathrm{a}} \pm 0.04$ \\
\hline Lymphocyte & $\%$ & $69.15 \pm 0.03$ & $69.17 \pm 0.03$ & $69.21 \pm 0.02$ & $69.23 \pm 0.02$ \\
\hline Monocyte & $\%$ & $00.85 \pm 0.006$ & $00.87 \pm 0.006$ & $01.01 \pm 0.028$ & $01.02 \pm 0.030$ \\
\hline Heterophil & $\%$ & $29.35 \pm 0.009$ & $29.28 \pm 0.033$ & $29.12 \pm 0.034$ & $29.05 \pm 0.026$ \\
\hline Eosinophil & $\%$ & $00.48 \pm 0.003$ & $00.50 \pm 0.015$ & $00.50 \pm 0.012$ & $00.51 \pm 0.009$ \\
\hline Basophil & $\%$ & $00.17 \pm 0.007$ & $00.18 \pm 0.003$ & $00.18 \pm 0.009$ & $00.19 \pm 0.015$ \\
\hline
\end{tabular}

(a)Each value is a mean of three replicates. (b)Means bearing different superscripts, differ significantly $(\mathrm{P}<0.05)$ row wise.

Table.4 Benefit cost ratio (per bird) of Pratapdhan under different treatments

\begin{tabular}{|c|c|c|c|c|}
\hline \multirow[t]{2}{*}{ Parameters } & \multicolumn{4}{|c|}{ Treatments } \\
\hline & $\mathrm{T}_{1}$ & $\mathrm{~T}_{2}$ & $\mathrm{~T}_{3}$ & $\mathrm{~T}_{4}$ \\
\hline Average weight $(\mathrm{Kg})$ & 1.13 & 1.16 & 1.20 & 1.14 \\
\hline $\begin{array}{l}\text { Average feed } \\
\text { consumption }(\mathrm{Kg})\end{array}$ & 3.20 & 3.07 & 3.01 & 3.23 \\
\hline Expenditure & \multicolumn{4}{|c|}{ Cost of Input (Rs./chick) } \\
\hline Chick & 35.00 & 35.00 & 35.00 & 35.00 \\
\hline Feed & 84.48 & 81.04 & 79.46 & 85.27 \\
\hline Ajwain & 00.00 & 00.77 & 01.50 & 2.42 \\
\hline Vaccine & 05.00 & 05.00 & 05.00 & 05.00 \\
\hline Labour & 08.75 & 08.75 & 08.75 & 08.75 \\
\hline Total cost & 133.23 & 130.56 & 129.71 & 136.44 \\
\hline Income & \multicolumn{4}{|c|}{ Output (Rs./bird) } \\
\hline $\begin{array}{l}\text { sale of bird (live } \\
\text { weight) } 200 / \mathrm{kg}\end{array}$ & 226 & 232 & 240 & 228 \\
\hline Benefit cost ratio & 1.70 & 1.78 & 1.85 & 1.67 \\
\hline
\end{tabular}


The data revealed that the benefit cost ratio was found highest 1.85 in $\mathrm{T}_{3}$ treatment followed by 1.78, 1.70 and 1.67 in $\mathrm{T}_{2}, \mathrm{~T}_{1}$ and $\mathrm{T}_{4}$ treatment, respectively. The cost of feed was $9.5 \%$ less in $0.2 \%$ Ajwain supplemented group $\left(\mathrm{T}_{3}\right)$ than control and it is the main reason for the increase of benefit cost ratio in the $T_{3}$ treatment even after inclusion of cost of Ajwain supplemented. These results are in agreement with the Hossain et al., (2014) who concluded that benefit cost ratio was significantly $(\mathrm{P}<0.05)$ better in garlic, ginger, black cumin, cinnamon and chilli supplemented group than the control. Eevuri and Putturu (2013) also reported a decrease in cost of feed from 6.2 to $13.5 \%$ on supplemented Tulsi, turmeric, Amla and Aloe-vera in broiler feed. Similar observations were also reported by Reddy et al., (2012), Yadava et al., (2009) and Molla et al., (2012). Although the Tazi et al., (2014) reported profitability ratio of 1.45 at $1 \%$ black pepper supplementation in broilers. Singh et al., (2015) reported that benefit cost ratio was significantly better in $1.5 \%$ WBGP supplemented group than other treatment groups.

The study revealed that supplementation of Ajwain to the diet of broiler chickens has beneficial effects on the haematological responses and the growth performance. The best results were obtained at higher levels of inclusion i.e. $0.2 \%$ Ajwain supplementation in mixed diet improves the haematology indices in chicken resulting in better growth. It is also profitable feed supplement and can be used as good alternative of antibiotics in broiler diet. Thus, the use of antibiotics in chickens should be discouraged as they can be replaced by Ajwain powder.

\section{References}

Aftab, K., Rahman, A. and Ghani, K.U. 1995. Blood pressure lowering action of active principle from Trachyspermum ammi (L) Sprague. Phyto-medicine. 2(1): 35-40.

Akhtar, M. S., Afzal, H. and Chaudhary, F. 1984. Preliminary in vitro antibacterial screening of Bakain, Gilo and Zarisk against Salmonella. Medicos. 9, 6-7.

Bentely, L. S., and Wrimen H. 1999. Medicinal Plants. Asiatic Publication House, New Delhi, India.

Devegowda G. 1996. Herbal medicines, an untapped treasure in poultry production. In: Proc. 20th World Poult. Congr. New Delhi, India.

Dwivedi, S. K., and Dubey, N. K. 1993. Potential use of the essential oil Trachyspermum ammi against seedborn fungi of guar. Mycopathologia. 121(2): 101-104.

Eevuri, T. R., and Putturu, R. 2013. Use of certain herbal preparation in broiler feeds. Vet World. 6(3): 172-179.

Elagib, H. A., El-Amin, W. I. A., Elamin, K. M. and Malik, H. E. 2013. Effect of dietary garlic (Allium sativum) supplementation as feed additive on broiler performance and blood profile. J. Anim. Sci. Adv. 3(4): 58-64.

Hossain, M. M., Howlader, A. J., Islam, M. N. and Beg, M. A. H. 2014. Evaluation of locally available herbs and spices on physical, biochemical and economical parameters on broiler production. Int. J. Pl. An and Env. Sci. 4(1): 317-323.

Kabir, S. M. L. 2009. The role of probiotics in the poultry industry. Int. J. Mol. Sci. 10(8): 3531- 3546.

Molla, M. R., Rahman, M. M. Akter, F. and Mostofa, M. 2012. Effects of Nishyinda, cinnamon and black pepper as growth promoters in broilers. Bangladesh Veterinarian. 29(2): 69-77.

Reddy, E. T., Reddy, P. S., Reddy, S.P. and Shakila, S. 2012. Effect of herbal preparations (Phyllanthus Emblica, Curcuma longa and Ocimum sanctum) 
on the performance of broilers. Tamil Nadu J Vet Anim Sci. 8(4): 209-14.

Sarkar, P. K., Chowdhury, S. D., Kabir, M. H., and Sarker, P. K. 2008. Comparative Study on the productivity and profitability of commercial broiler, cockerel of a layer strain and cross-bred $(\mathrm{RIR} \times$ Fayoumi) Chicks. Bangladesh J Anim Sci. 37(2): 89-98.

Sethy, K., Swain, P., Behera, K., Nayak, S.M., Barik, S.R., Patro, P. and Meher, P. 2016. Effect of turmeric (Curcuma longa) supplementation on growth and blood chemistry of broilers. Anim Med Res. 6(1): 75-79.

Siddiqui, M.F., Kolte, A.Y. and Waghmare, S.P. 2007. Effect of Withania somnifera and Tinospora cordifolia on haematological Singh, J., Sethi, A. P. S., Sikka, S. S., Chatli, M. K. and Kumar, P. 2015. Effect of sun dried whole bulb garlic powder on growth, carcass characteristics and meat quality of commercial broilers. Indian J. Ani. Sci. 85(1): 67-71.

Sojoudi, M. R., Dadashbeiki, M. and Bouyeh, M. 2012. Effects of different levels of symbiotic TechnoMos on broiler performance. Res Opin Anim Vet Sci. 2(4): 243-248.

Srivastava, K.C. 1988. Extract of Trachyspermum ammi shows antiaggregatory effects and alters arachidonic acid metabolism in human platelets. Prostaglandins Leukot Essent Fatty Acids. 33 (1): 1-6.

Tazi, S. M., Mukhtar, M. A., Mohamed, K. A. and Tabidi, M. H. 2014. Effect of using black pepper as natural feed additive on performance and carcass quality of broiler chicks. Global Advanced research Journal of Agricultural Science. 3(1): 113-18.

Yadava, P. K., Niranjan, P. S., Udeybir, K. S. and Verma, D.N. 2009. Performance of

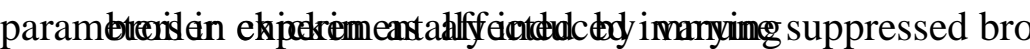
levels of multi enzyme supplementation. Anim Nutr Feed Techn. 9(1): 103-108.

Yang, Y., Iji, P. A. and Choct, M. 2009. Dietary modulation of gut microflora in broiler chickens: a review of the role of six kinds of alternatives to in-feed antibiotics. Worlds Poult Sci J. 65, 97 114.

\section{How to cite this article:}

Anurag, Sarita Kumari and Attar Uddin. 2018. Evaluation of Dietary Supplementation of Ajwain on the Hematological and Economical Parameters of Pratapdhan Chickens. Int.J.Curr.Microbiol.App.Sci. 7(02): 261-267. doi: https://doi.org/10.20546/ijcmas.2018.702.034 